\title{
Utilization by the bacon pig of dehulled sunflower meal associated to protein-rich peas
}

\author{
J. CHAUVEL ${ }^{(1)}$, R. GRANIER (2)
}

Institut Technique du Porc

(1) Domaine de la Motte-au-Vicomte, B.P. 3, 35650 Le Rheu

(2) Station Expérimentale Les Cabrières, 12200 Villefranche-de-Rouergue

Sunflower meal and protein rich peas are complementary for energy and lysine. To study the utilization by the fattening pig of dehulled sunflower meal associated with protein rich peas, a control diet based on cereals, peas and soyabean (diet 1) was compared to three diets : a diet containing 10 p. 100 sunflower meal without peas (diet 2), a diet containing 10 p. 100 sunflower meal and 20 p. 100 peas (diet 3) and a diet containing 12 p. 100 rapeseed 00 meal and 20 p. 100 peas (diet 4). A total of 128 animals were used, 64 castrated males and 64 females, i.e. 16 animals per treatment. The diet was offered according to a progressive and continuous feeding scheme.

Compared to the control diet, dehulled sunflower meal depressed the performance by 8 p. 100 . Peas associated with sunflower meal improved the performance by $3 \mathrm{p}$. 100 compared to sunflower meal without peas (diet 2). Diet 4 (rapeseed meal and peas) led to the same results as the control diet.

Thus, the presence of protein rich peas only partially counterbalances the lower performance obtained with 10 p. 100 dehulled sunflower meal.

\section{Contribution to the study of tryptophan requirement in the growing pig}

\author{
T. KIENER, J. LOUGNON, J.C. JUGY
}

\section{A.E.C. (Service Développement Alimentation Animale), 03600 Commentry}

Tryptophan is the second limiting amino acid of pig feeds containing maize or its derivatives, plant proteins and meat and bone meal. Three experiments were carried out at the A.E.C. experimental farm to study the tryptophan requirement of growing pigs.

In the first experiment, three diets containing $15.8 \mathrm{p} .100$ protein and $0.76 \mathrm{p} .100$ lysine were compared. Replacement of soyabean by maize gluten brought about a decrease in the performance which was counterbalanced by an addition of L-tryptophan. Addition of $1.3 \mathrm{~g}$ tryptophan $/ \mathrm{kg}$ of diet was insufficient to support optimal performance.

The level of tryptophan required to optimize feed efficiency was determined in the second experiment. Three diets containing $0.13-0.15$ and $0.17 \mathrm{p}$. 100 tryptophan, respectively were compared. Over the $25-60 \mathrm{~kg}$ live weight range, the feed conversion ratio was significantly lower with the highest level of tryptophan than with the other two levels (2.47 versus 2.61 and 2.54$)$. The level of tryptophan required to obtain the best performance between $25-60 \mathrm{~kg}$ is $0.17 \mathrm{p} .100$ of the diet, which represents 21 p. 100 of the lysine requirement or $0.52 \mathrm{~g} / 1000 \mathrm{Kcal} \mathrm{DE}$.

The third experiment showed that tryptophan deficiency between 25 and $60 \mathrm{~kg}$ had a negative effect on the further performance even when animals were fed a balanced diet after $60 \mathrm{~kg}$. When a single feed is offered during the fattening period, it is advisable to use the level of tryptophan recommended above. 